\title{
Acetabular fractures treated surgically: Which of the parameters affect prognosis
}

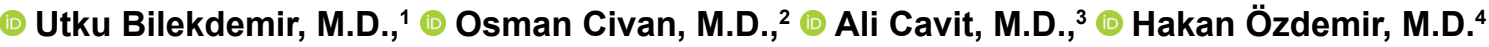

\author{
${ }^{1}$ Department of Orthopaedics and Traumatology, Silifke State Hospital, Mersin-Turkey \\ ${ }^{2}$ Department of Orthopaedics and Traumatology, Elmalı State Hospital, Antalya-Turkey \\ ${ }^{3}$ Department of Orthopaedics and Traumatology, Uludağ University Faculty of Medicine, Bursa-Turkey \\ ${ }^{4}$ Department of Orthopaedics and Traumatology, Akdeniz University Faculty of Medicine, Antalya-Turkey
}

\begin{abstract}
BACKGROUND: This study aims to evaluate the surgical approaches, complications, clinical and radiological findings in acetabular fractures treated with surgical methods and to determine the parameters affecting prognosis.

METHODS: Out of 144 patients undergone surgical treatment with the diagnosis of displaced acetabular fractures between 1994 and 2014 , a total of 103 patients with 75 male and 28 female with a mean age of 36.3 years (range 19-67 years) whom clinical and radiologic follow-ups (mean: 34 months, range 2-8 years) were performed at least for two years were included in this study.

RESULTS: Clinically excellent to good outcomes were obtained in $64 \%$ of the patients and moderate to poor outcomes were recorded in $36 \%$ of the patients, while radiologically excellent to good outcomes were achieved in $57.3 \%$ of the patients and moderate to poor outcomes were recorded in $42.7 \%$ of the patients. Presence of one of the complications, creating mechanical block (chi-square $p<0.00 \mathrm{I}$ ), complex fractures (chi-square $p=0.023)$, increased duration between trauma and operation $(p=0.039)$, operational time taking longer than six hours (chi-square $p<0.00 \mathrm{I}$ ), more than $3 \mathrm{~mm}$ intra-articular step (Fisher's $p=0.033$ ), avascular necrosis $(p<0.00 \mathrm{I}$ ), arthritis $(p=0.006)$ and heterotopic ossification $(p=0.007)$ worsened the clinical outcomes (chi-square $p<0.00 \mathrm{I})$. The age of the patient was not effective on the clinical outcome $(p=0.46 \mathrm{I})$.
\end{abstract}

CONCLUSION: It was found that three major parameters affecting the prognosis of acetabular fractures are as follows: type of fracture, operational time and reduction quality. The duration between trauma and operation indirectly affects the outcomes. Avascular necrosis, heterotopic ossification and arthritis may cause negative effects only on long term outcomes.

Keywords: Acetabular fractures; acetabulum; fractures; pelvic fractures; prognosis of acetabular fractures; surgical treatment of acetabular fractures.

\section{INTRODUCTION}

Surgical treatment techniques of acetabular fractures (AFs) are still one of the important and discussed topics due to the complex anatomy of this region, severity of complications and variety of factors affecting prognosis. ${ }^{[1-5]}$

The present study aims to investigate the factors affecting prognosis by evaluating: the surgical approaches applied for displaced AFs, complications and clinically and radiological results.

\section{MATERIALS AND METHODS}

Among 219 patients with 219 pelvic and AFs underwent surgical treatment between 1994 and 20I4, out of 144 patients surgically treated for displaced AFs, a total of 103 patients (75 male, 28 female), mean age of 36.3 (range 19-67 years), were followed-up at least for two years (mean follow-up duration: 34 months; range 2-8 years) included in this study. Left acetabular fracture (AF) in 57 patients and right $A F$ in 46 patients; 57 of the fractures caused by in-

Cite this article as: Bilekdemir U, Civan O, Cavit A, Özdemir H. Acetabular fractures treated surgically: Which of the parameters affect prognosis. Ulus Travma Acil Cerrahi Derg 2020;26:265-273.

Address for correspondence: Osman Civan, M.D.

Elmalı Devlet Hastanesi, Ortopedi ve Travmatoloji Kliniği, Antalya, Turkey

Tel: +90242 - 6188300 E-mail: civanosman@gmail.com

Ulus Travma Acil Cerrahi Derg 2020;26(2):265-273 DOI: 10.14744/tjtes.2019.88472 Submitted: 01.03.2019 Accepted: 02.07.2019 Online: 24.02.2020

Copyright 2020 Turkish Association of Trauma and Emergency Surgery 
vehicle accident, 3 I out-of-vehicle accidents and 15 falling from a height.

Three radiographic series described by Judet used with Computerized Tomography $(\mathrm{CT})$ and $3 \mathrm{D}$ reconstruction methods used for diagnosis, while the classification of the fractures was made according to the classification described by Judet and Letournel. ${ }^{[6]}$

Surgical treatment was performed for the fractures with displacement $>3 \mathrm{~mm}$, roof arch angle $<45^{\circ}$, intact posterior wall fragment $<50 \%$, in the presence of intra-articular free fragment, marginal impaction $>3 \mathrm{~mm}$ and in femoral head fractures or the fractures accompanied by sciatic nerve lesions. The fourth author (H.Ö.) attended to all operations and worked for the follow-up of all patients.

Low-molecular-weight heparin (LMWH) was used against the risk of thromboembolism from hospitalization of the patient up to the postoperative $6^{\text {th }}$ week. Patients were put on compression socks up to the $3^{\text {rd }}$ month for the same purpose.

Infection prophylaxis was applied using $\left.\right|^{\text {st }}$ generation cephalosporin, beginning 12 hours before the surgery, repeating once every three hours during the surgery and three doses up to the postoperative $3^{\text {rd }}$ day.

Prophylaxis for heterotopic ossification (HO) was applied using Indometazine $75 \mathrm{mg}$, started on postoperative Ist day, and continued over six weeks. Displacement of the articular surface was measured with postoperative acetabular graphy series and evaluated according to Matta criteria. A displacement of $0-1 \mathrm{~mm}$ was considered as anatomic, $1-3 \mathrm{~mm}$ acceptable and $\geq 3 \mathrm{~mm}$ as inadequate reduction.

Knee and hip isometric exercises were initiated on the postoperative 2 nd day. All of the patients were mobilized by a double crutch without weight-bearing in the same weeks after providing the security of the operation area.

Clinical and radiological results were evaluated through the scoring system of Merle D'Aubigne modified by Matta ${ }^{[7]}$ (Table I). Statistical analysis was performed using SPSS (Statistical Package for Social Sciences for Windows 18.0) software. Spearman's correlation test was used to investigate the relationships of the quantitative data with each other. Pearson's chi-square test or Fisher's exact test were used to evaluate the connections between categorical data. P-values less than 0.05 were considered as statistically significant results.

\section{RESULTS}

Twenty-four (23.3\%) of the patients had isolated AF, and 79 (76.7\%) had AF accompanied with another injury (Table 2).

Thirty-four (33\%) of the fractures were simple and $69(67 \%)$ were complex type fractures. Posterior wall fracture (16,6\%) was the most common type among simple fractures; the most frequent type in both complex fractures and among all fractures was double-column AF (25.3\%) (Table 3).

Table I. Clinical and radiological criteria at fallow-up

\begin{tabular}{|c|c|c|c|c|c|}
\hline \multicolumn{6}{|l|}{ Clinical criteria } \\
\hline \multicolumn{2}{|l|}{ Pain } & \multicolumn{2}{|l|}{ Walking } & \multicolumn{2}{|c|}{ Range of motion } \\
\hline None & 6 & Normal & 6 & $95 \%-100 \%$ & 6 \\
\hline Slight or intermittent & 5 & No cane but slight limp & 5 & $80 \%-94 \%$ & 5 \\
\hline After walking but resolves & 4 & Long distance with cane or crutch & 4 & $70 \%-79 \%$ & 4 \\
\hline Moderately severe but patient is able to walk & 3 & Limited even with support & 3 & $60 \%-69 \%$ & 3 \\
\hline \multirow[t]{2}{*}{ Severe, prevents walking } & 2 & Very limited & 2 & $50 \%-59 \%$ & 2 \\
\hline & & Unable to walk & 1 & $<50 \%$ & I \\
\hline Clinical grade & & \multicolumn{4}{|c|}{ Excellent: I8 Good: 17-16-15 Fair: 14-13 Poor: $<13$} \\
\hline \multicolumn{6}{|l|}{ Radiographic criteria } \\
\hline Excellent & & \multicolumn{4}{|l|}{ Normal appearance of the hip } \\
\hline Good & & \multicolumn{4}{|c|}{ Small osteophytes, moderate $(\mathrm{I} \mathrm{mm})$ narrowing of joint \& minimum sclerosis } \\
\hline Fair & & \multicolumn{4}{|c|}{$\begin{array}{l}\text { Intermediate changes, moderate osteophytes, Moderate }(<50 \%) \text { narrowing of } \\
\text { joint \& moderate sclerosis }\end{array}$} \\
\hline Poor & & \multicolumn{4}{|c|}{$\begin{array}{l}\text { Advanced changes, large osteophytes, severe }(>50 \%) \text { narrowing of the joint, } \\
\text { collapse or wear of the femoral head, and acetabular wear. Collapse or wear } \\
\text { of the femoral head, and acetabular wear }\end{array}$} \\
\hline
\end{tabular}


Table 2. Additional injuries to acetabulum fractures

\begin{tabular}{lcc}
\hline Additional injuries & $\mathbf{n}$ & $\%$ \\
\hline Exremity injury & 56 & 52.9 \\
Hip luxation & 23 & 21.6 \\
Intracranial injury & 8 & 7.6 \\
Intra-abdominal injury & 7 & 6.6 \\
Chest injury & 6 & 5.7 \\
Nerve paralysis & 3 & 2.8 \\
Spinal injury & 3 & 2.8 \\
\hline
\end{tabular}

The posterior hip dislocation was found in 19 (I7.9\%) patients and central hip dislocation in four $(3.7 \%)$ patients. Neurological deficit due to fracture was identified in two patients with the posterior hip dislocation (one sciatic and one peroneal nerve), and in one patient with transverse + posterior wall fracture (peroneal nerve).

The duration between trauma and operation (T-O time) was between 0 and 28 days (mean 8.3 days). Surgical treatment was performed on the same day of the trauma in five patients, within one and 20 days after trauma (mean 8.3 days) in 96 patients and on the $21^{\text {st }}$ and $28^{\text {th }}$ days in each one patient (Table 4).

Surgical procedures were performed using Kocher Langenbeck (K-L), llioinguinal (II), Iliofemoral (IF), Triradiate (TR), Modified Transtrochanteric (MT) and combined incisions (Cl) (Table 3).

The anatomic reduction was achieved in 78 (75.7\%), acceptable reduction in 15 (14.6\%) and non-acceptable reduction in $10(9.7 \%)$ patients (Table 3$)$.

Reconstruction plates with screws were used in 95 of 103 patients. Semi-tubular and reconstruction plates with screws were used together in seven patients and one patient was treated using only screws. These types of materials used in the surgical procedure had no significant effect on the clinical and radiological outcomes.

Five patients had superficial and five patients had a deep infection during follow-up (Tables 3, 4). Infection was regressed with antibiotic therapy in patients who had a superficial infection and after repetitive debridements and antibiotherapy in those with deep infection. None of the patients required removal of the implant.

Avascular necrosis (AVN) was found in 16 (15.5\%) patients. AVN was seen in mean 22.8 months (range 6-52 months). The relationship between types of incision and types of fractures was reported in Table 3.

Despite indomethacin prophylaxis, $\mathrm{HO}$, varying between stages $I$ and 4 according to Brooker classification ${ }^{[8]}$ was ob- served in 17 (16.5\%) patients (Fig. I). Meralgia due to postoperative lateral femoral cutaneous nerve damage was seen in 2 of 20 patients operated by II incision and I of 3 operated using IF incision. Relationship between paralysis, $\mathrm{HO}$ and type of fractures, type of incision were all introduced in Table 3. None of the patients who had paralysis showed complete healing.

Symptomatic deep vein thrombosis and pulmonary embolism have not been observed except for a 63-year-old patient with posterior wall + column fracture.

Excellent to good clinical outcomes were recorded in $79.4 \%$ of the simple fractures (Fig. 2) and $56.5 \%$ of the complex fractures (Fig. 3). A significant correlation was found between the type of fracture and clinical outcome. (chi-square $=5.185$ $p=0.023)$.

There was a significant correlation between $\mathrm{T}-\mathrm{O}$ time and clinical outcomes $(r=0.204 p=0.039)$. However, when T-O time was categorized as 0-7 days, 8-14 days and 15-28 days; it did not show a significant effect on clinical outcome (chisquare $=1.365 \mathrm{p}=0.505)$.

Clinic outcomes were worsened by increasing at the operational time $(r=0.318 p=0.001)$. When the operational time was categorized as 0-3 hours, 3-6 hours and $>6$ hours, it statistically significantly affected clinical outcomes of the groups (chi-square $=15.752 \mathrm{p}<0.001$ ). The relationship of the groups with each other was examined in order to find out which group caused significant effect. An operational time between 0-3 hours and 3-6 hours did not significantly affect clinical outcomes (Fisher's<0.999). However, there was a statistically significant correlation between clinical outcomes of the patients with an operational time of $0-3$ hours and $>6$

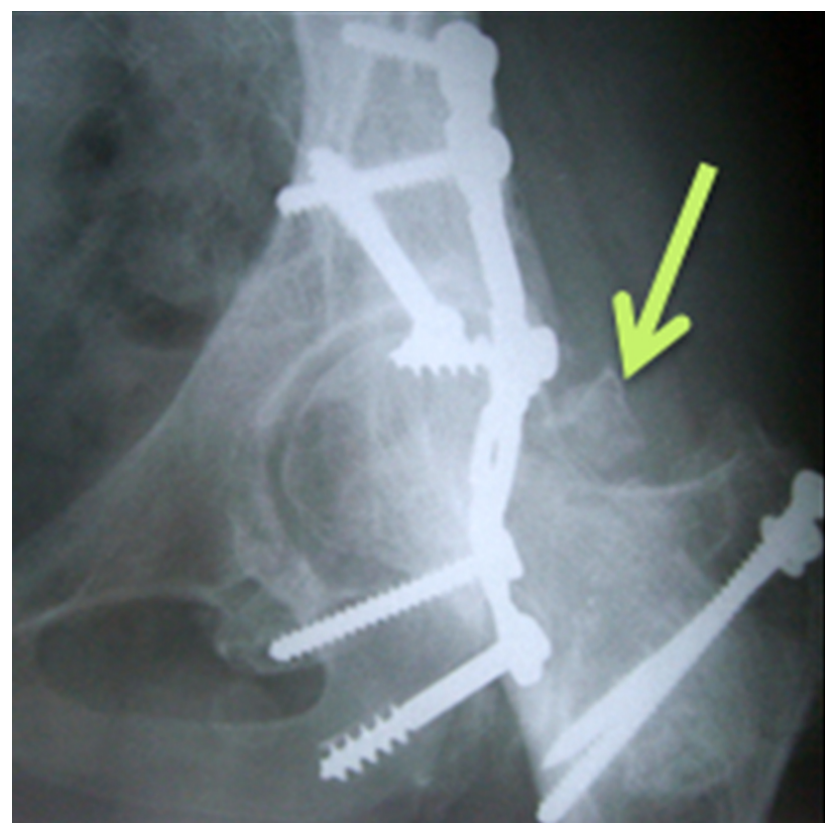

Figure 1. Heterotopic ossification (shown with arrow). 


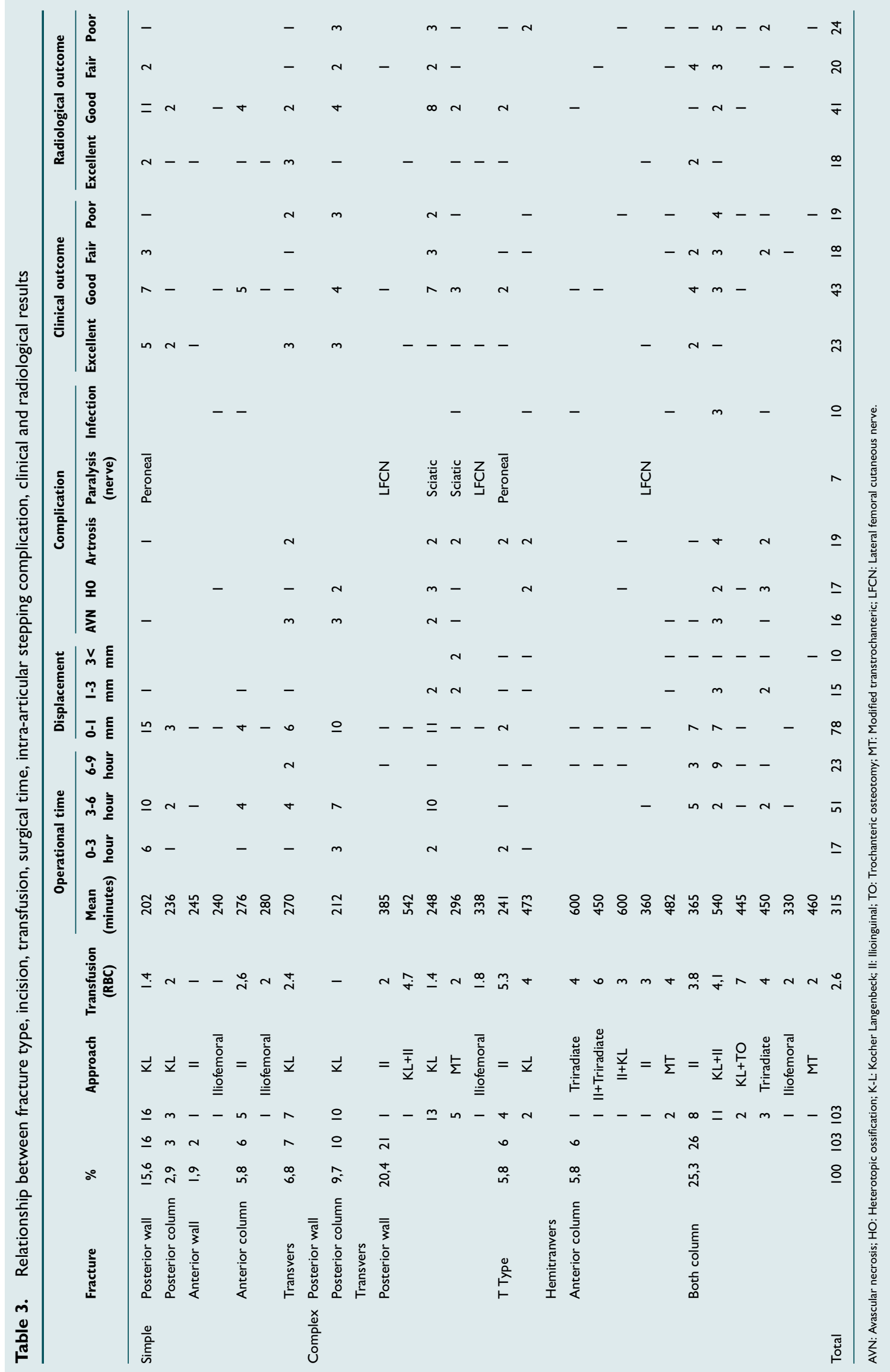




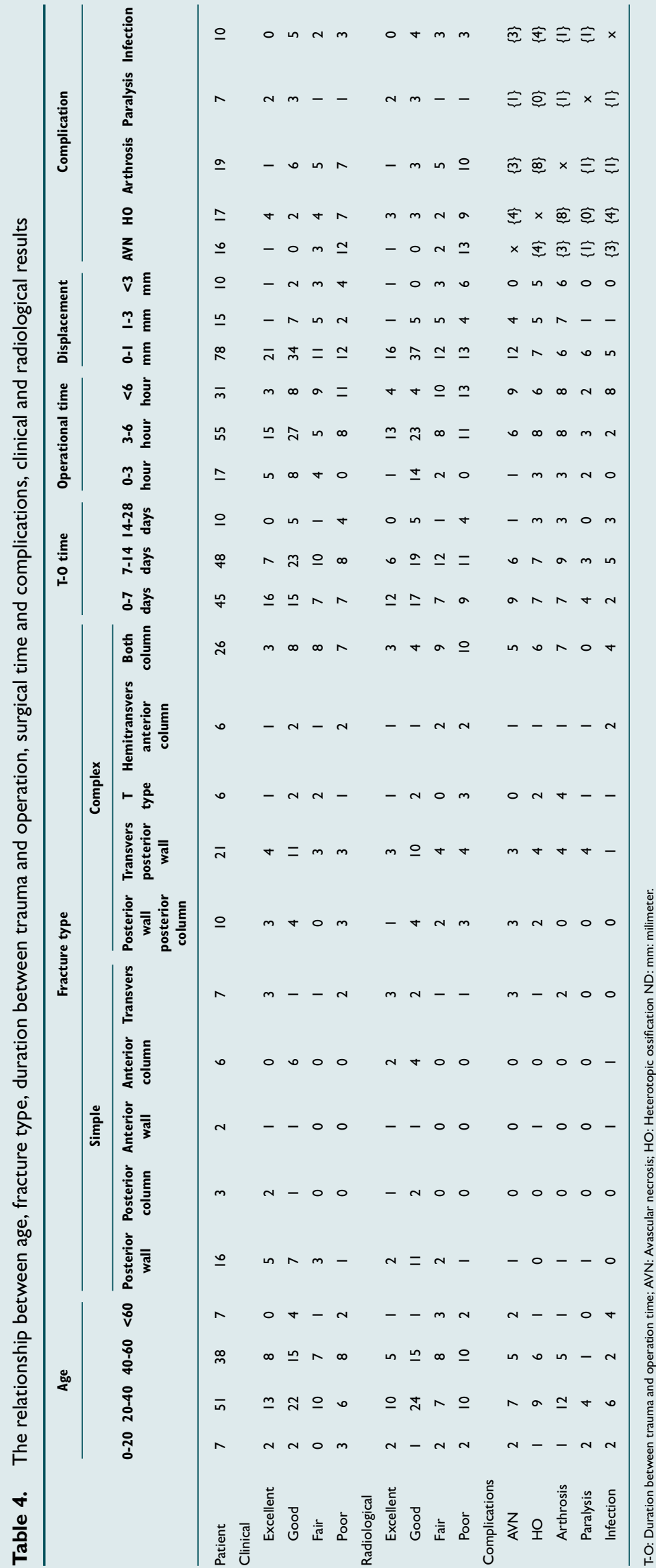

hours and those with an operational time of 3-6 hours and $>6$ hours (chi-square $=7.378 p=0.007$ and chi-square $=14.010 p<0.001$; respectively). Briefly, the clinical outcome was worsened with a surgery lasting longer than six hours.

Clinical outcome was also worsened with the increase of the postoperative fracture displacement $(r=0.248 p=0.0 \mathrm{I})$. When postoperative steps were categorized as $0-1 \mathrm{~mm}, \mathrm{I}-3 \mathrm{~mm}$ and $>3 \mathrm{~mm}$; no statistically significant difference was found between clinical outcomes of the patients with a step between $0-1 \mathrm{~mm}$ and a step between I-3 mm (Fisher's $=0.232$ ). When step groups were categorized as 0-3 and >3 mm, excellent to good outcomes were found in $67.7 \%$ of the patients with a step between 0-3 mm, while this rate is $30 \%$ in the patients with a step $>3 \mathrm{~mm}$ (Fisher's $p=0.033$ ).

When the step increases, the incidence of arthritis and $\mathrm{HO}$ also increased. Arthritis was found in $14 \%$ of the patients with the step between $0-3 \mathrm{~mm}$ and $60 \%$ of those with the step $>3 \mathrm{~mm}$ (Fisher's $p=0.002$ ); while $\mathrm{HO}$ was observed in $12.9 \%$ of the patients with the step between $0-3 \mathrm{~mm}$ and $50 \%$ of those with the step $>3 \mathrm{~mm}$ (Fisher's $\mathrm{p}=0.010$ ).

A significant correlation was found between complication occurrence and type of fracture. Complications were developed in $23.5 \%$ of the simple fractures and $58 \%$ of the complex fractures (chi-square $=10.857 \mathrm{p}=0.00 \mathrm{I}$ ).

Clinical outcomes were excellence to good in $74.7 \%$ of the patients without AVN (chisquare $=27.519 p<0.001$ ), $70.2 \%$ of the patients without arthritis (chi-square $=7.508 \quad p=0.006$ ) and $69,8 \%$ of the patients without $\mathrm{HO}$ (chisquare $=7.328 \mathrm{p}=0.007$ ).

There was a significant correlation between clinical and radiological outcomes. Radiologically excellent to good outcomes were recorded in $83.3 \%$ of the patients with excellent to good and $10.8 \%$ of those with moderate to poor clinical outcomes (chi-square $=50.959 p<0.00 \mathrm{I}$ ). It was determined that clinical and radiological outcomes were approximately $70 \%$ compatible with each other $($ kappa $=0.696)$.

\section{DISCUSSION}

Waiting for longer than 10 days for the surgical treatment of AFs causes difficulty in reduction due to the formation of granulation tissue, while 

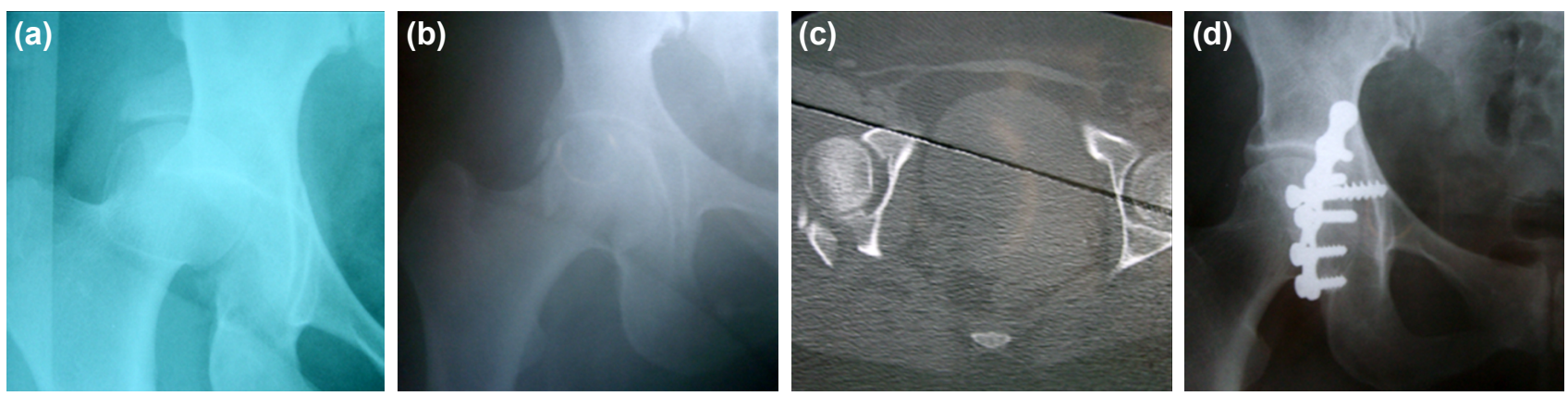

Figure 2. 42 years female, K-L incision, clinically excellent result; (a) Preoperative x-ray shows dislocated hip with posterior wall type acetabular fracture. (B) X-ray after reduction of the hip. (c) Preoperative CT. (d) $7^{\text {th }}$ year, excellent radiological result.
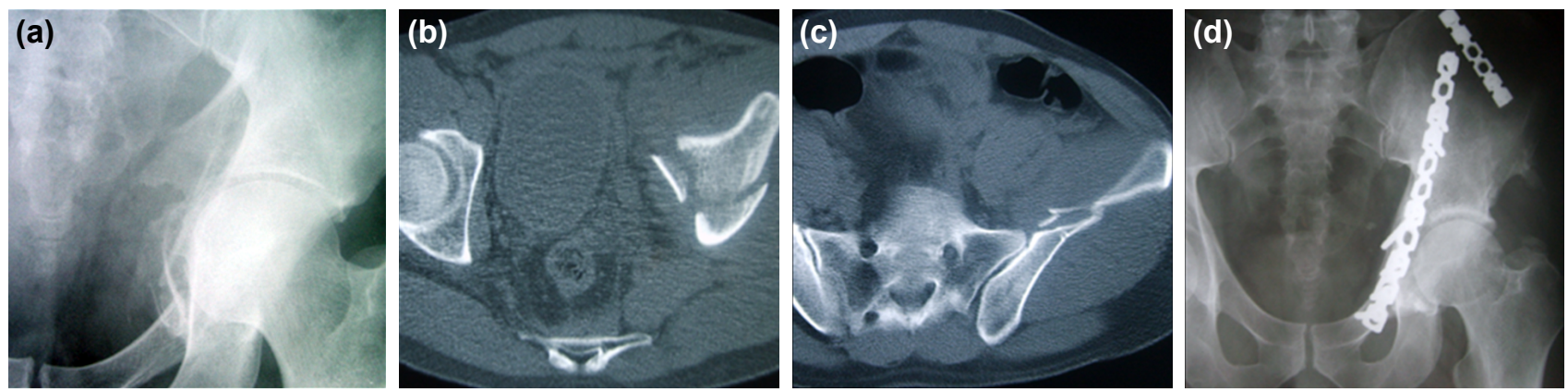

Figure 3. 31 years old male, II incision, clinically good results; (a) Preoperative x-ray. (b) Preoperative CT. (c) Preoperative CT scan shows iliac fracture. (d) $5^{\text {th }}$ year postoperative $x$-ray shows good radiological result.

delays for longer than three weeks lead to reduction and stabilization problems due to resorption. ${ }^{[9-11]}$ The mean T-O time was 8.3 days in patients in our study groups. It was found that if T-O time is prolonged, clinical outcome was worsened and operational time was prolonged and likely to become an anatomic reduction decreased in the cases that $\mathrm{T}-\mathrm{O}$ time exceeding 14 days. Although not statistically significant, an interesting result found regarding T-O time was as follows: extensile or combined incisions were needed in $38.8 \%$ of the patients with T-O time between $7-14$ days and $55.5 \%$ in the patients with a operation time longer than 14 days. All these data are important in suggesting that performing surgery for AFs within the first two weeks would mean a smaller incision, shorter duration of anesthesia, less soft tissue damage and better clinical and radiological outcomes, and the vast majority of the literature is consistent with our data. ${ }^{[12,13]}$

Although no randomized controlled trial was found in the literature to compare two different surgical approaches, recently, there is a tendency to shift from extensile or TR incisions toward K-L incisions, ${ }^{[9,14,15]}$ whereas five different incisions were used in our study, the most commonly incisions used in the vast majority (84.5\%) of the patients included $\mathrm{KL}$, $\mathrm{II}$ and a combination of them. Surgeons trained in the last ten years may never have seen extensile approaches other than in a laboratory or book, and these approaches are likely to become historical within the next decade or two. ${ }^{[1]}$

TR incision is a surgical approach that should be abondened due to the high incidence of $\mathrm{HO}$ and infections. MT incision and its numerous disadvantages are reported in the literature, is not an approach that should be avoided as reported in the literature $^{[8,17]}$ because of leading shortened operational time, low incidence of $\mathrm{HO}$ and infections as demonstrated in the present study; also can be used as an alternative to extensile and combined approaches in fragmented, complicated fractures.

Studies in the literature report localization and amount of the displacement, compliance between the femoral head and acetabulum and roof restoration as the most important prognostic indicators of AFs. ${ }^{[18,19]}$ Rowe and Lowell ${ }^{[12]}$ reported poor treatment results in cases of a displacement $>3 \mathrm{~mm}$, while Matta ${ }^{[15]}$ reported the acceptable amount of displacement as $3 \mathrm{~mm}$. In our study, clinical outcome was statistically worsened as the intra-articular step exceeds $3 \mathrm{~mm}$ while excellent to good outcomes were achieved in $70.5 \%$ of the patients could be reduced anatomically. Because of the $29.5 \%$ moderate to the poor rate of anatomically reduced fractures, it is important to show that anatomic reduction is not alone prognostic factor for AFs.

In the literature, the infection rate after AFs treated surgically have been reported between $4-5 \%$ and $19 \%$ is the highest one. ${ }^{[9,20,21]}$ Infection rate, $9.7 \%$ recorded in our study, is higher than the literature because of the use of combined or extensile incisions in one-third of the patients and prolonged operational time due to lack of experience, especially in the first years (operational time was over eight hours in almost all patients who developed infections). The finding which is needed to be deliberated is that the infection rate is higher 
in combined and extensile incisions by four times compared to single or limited incisions. This is meaningful for suggesting that single and limited incisions should be preferred, while extensile and combined incisions should be avoided.

The literature reports the incidence of $\mathrm{HO}$ as $15-50 \%$ and $\mathrm{HO}$ blocking hip joint movement (Brooker type III-IV) as 7\%, ${ }^{[8,22-23]}$ while in our study, the incidence of $\mathrm{HO}$ was found as $16.5 \%$ (I7 patients) and $\mathrm{HO}$ blocking hip joint movement as $4.9 \%$. The incidence of $\mathrm{HO}$ increased in all extensile incisions except MT. The rate of $\mathrm{HO}$ was $15 \%$ in the patients operated within two weeks after the trauma, while this rate raised to $30 \%$ after the $2^{\text {nd }}$ week. $\mathrm{HO}$ was observed in $15.2 \%$ of the patients with the operational time between 0-6 hours and $19.4 \%$ in those with operations ending longer than six hours. The incidence of $\mathrm{HO}$ was found to be significantly decreased in simple fractures and in the cases with a step $<3 \mathrm{~mm}$ could be provided. These data indicate that operating patients within the first two weeks, operational times shorter than six hours and preference of limited surgical incisions are important to avoid $\mathrm{HO}$.

Another late complication of AFs is AVN. Letournel ${ }^{[24]}$ reported the rate of $\mathrm{AVN}$ as $5.6 \%$, Tile ${ }^{[5]}$ as $18 \%$ and Alonso ${ }^{[4]}$ as $2-25 \%$. AVN is seen in a combination with arthrosis in the cases with delayed reduction and becomes radiologically marked within two years following injury. In our study, AVN was found in $15.5 \%$ of the patients. This rate was $26.3 \%$ in patients with posterior hip dislocation and $25 \%$ in those with central dislocation. Although not statistically significant, onethird of the patients who developed AVN had posterior dislocation and AVN was identified in one-third of the patients with posterior dislocation. These findings suggest a relationship between them. AVN was found in $20 \%$ of the patients operated within the first week after trauma; $12.5 \%$ of the patients operated between I-2 weeks, and $10 \%$ of the patients operated after the 2nd week. Unlike information from the literature, in our study, prolonged T-O time did not increase the incidence of $A V N$. Posterior incisions (KL, MT, combined, TR) used in 15 of 16 patients developed AVN. AVN was found in $5.8 \%$ of the patients with an operational time between 0-3 hours, $10.9 \%$ of the patients with an operational time between 3-6 hours, and $29 \%$ of the patients with an operational time longer than six hours. The risk of AVN was increased by 2.7 times in the surgeries ending longer than six hours, compared to ending between 3-6 hours. These data demonstrate that the presence of dislocation, operational time and type of incision are parameters affecting the development of AVN. Although unlike the literature, increased $\mathrm{T}-\mathrm{O}$ time was found as not increasing the incidence of AVN. It should be remembered that $98 \%$ of AVNs develop at the time of trauma and emergency reduction of the dislocation may prevent the development of AVN.

Arthritis is one of the late complications of AFs. Several predisposing factors have been reported as the risk of arthritis, including cartilage damage at the time of trauma, collapses that may develop at the late period, multi fragmentation of the fracture, localization, amount of the residual displacement and patients $>40$ years-old. The most important factor is residual displacement caused by inadequate reduction. There is a consensus on that displacement $>3 \mathrm{~mm}$ would result in arthritis. $[1,25,26]$ Tile reported the rate of arthrosis as $10 \%$ in anatomic reduction and $36 \%$ in inadequate reduction. ${ }^{[27]}$ In our study, arthritis was identified in $18.5 \%$ of the patients. Of the patients with arthritis identified, $84.2 \%$ had complex and $15.8 \%$ had simple fractures. Arthritis was observed in 14\% of the patients with a step between $0-3 \mathrm{~mm}$ and $60 \%$ of the patients with a step $>3 \mathrm{~mm}$ (Fisher's $p=0.002$ ). Although the incidence of arthritis is significantly increased when the amount of displacement exceeds $3 \mathrm{~mm}$, arthritis was found in $7.7 \%$ of the patients with anatomic reduction provided, and these findings suggest that other predisposing factors also play a role. Arthritis was found in $17.2 \%$ of the patients operated within the first two weeks after the trauma, while this rate was found as $30 \%$ in those operated after two weeks. Although not statistically significant, I.8 times, the difference between these two groups is obviously seen. Our statistical analysis indicates that the incidence of arthritis is significantly higher in the complex fractures than the simple fractures (chi-square $p=0.077$ ), and also arthritis was recorded in $66.6 \%$ of $\mathrm{T}$ type fractures and $26.9 \%$ of double-column fractures. The most remarkable point is that $57.9 \%$ of all identified arthritis cases were recorded in these two types of fractures. Based on this information, it can be said that the severity of trauma causing fracture is responsible for the type of fracture at least, T-O time, and reduction quality are responsible for the development of arthritis.

In our study, clinical outcomes were statistically significantly worsened in cases of complex fractures, prolonged T-O time, surgeries taking longer than six hours, intra-articular step $>3$ $\mathrm{mm}$ and presence of any of AVN, arthritis and $\mathrm{HO}$. However, the age of the patients had no significant effect on clinical outcomes. All these results indicate that evaluating patients' pretraumatic functional status rather than age is more significant when making a decision for the surgical treatment of AFs. It should be kept in mind that technological developments could help us, especially for the treatment of complex type fractures. For example, 3D printing assisted surgical technique would be preferred for these types. ${ }^{[28]}$ It is difficult to be sure, but one would hope that the advances made during this time have led to improvements in outcome and that if modern-day techniques had been available to Letournel, even better results would be seen. ${ }^{[16]}$

Letournel pointed out that clinical outcomes are better than radiological ones. This is because of the late onset of patients' complaints despite the earlier onset of radiographic arthrosis findings. ${ }^{[24]}$ According to Matta, excellent anatomic reduction term is used based on radiologic imaging, which often causes misleading. ${ }^{[15]}$ The results of our study support this information. 
In conclusion, results obtained in this study demonstrated that type of fracture, operational time and reduction quality are the three major parameters affecting the prognosis of AFs that are surgically treated. T-O time indirectly affects the outcomes and avascular necrosis, heterotopic ossification and arthritis bring on negative effects only on long term outcomes.

Ethics Committee Approval: Approved by the local ethics committee.

Peer-review: Internally peer-reviewed.

Authorship Contributions: Concept: H.Ö., U.B., O.C; Design: H.Ö., U.B.; Supervision: H.Ö.; Materials: H.Ö., U.B.; Data: H.Ö., U.B., O.C., A.C.; Analysis: H.Ö., U.B., O.C., A.C.; Literature search: H.Ö., U.B., O.C., A.C.; Writing: H.Ö., U.B., O.C., A.C.; Critical revision: H.Ö., U.B., O.C., A.C.

Conflict of Interest: None declared.

Financial Disclosure: The autors declared that this study has received no financial support.

\section{REFERENCES}

1. Letournel E, Judet R. Surgical approaches to the acetabulum. In: Elson RA, editor. Fractures of the Acetabulum. Berlin, Heidelberg: Springer; 1993. p. 363-97. [CrossRef]

2. Matta JM. Operative treatment of acetabular fractures through the ilioinguinal approach. A 10-year perspective. Clinical Orthopaedics and Related Research 1994;305:10-9. [CrossRef]

3. Stannard JP, Alonso JE. Controversies in acetabular fractures. Clin Orthop Relat Res 1998;353:74-80. [CrossRef]

4. Alonso JE, Davila R, Bradley E. Extended iliofemoral versus triradiate approaches in management of associated acetabular fractures. Clin Orthop Relat Res 1994;305:81-7. [CrossRef]

5. Tile M. Fracture of the acetabulum. In: Rockwood CA, Green DP, editors. Rockwood and Green's fractures in adults. 4th ed. Philadelphia: Lippincott-Raven; 1996. p. 1617-58.

6. Judet R, Judet J, Letournel E. Fractures of the Acetabulum: Classification and Surgical Approaches for Open Reduction. Preliminary Report. JBJS American Vol 1964;46:1615-46. [CrossRef]

7. Qadir RI, Bukhari SI. Outcome of Operative Treatment of Acetabular Fractures: Short Term Follow-Up. J Ayub Med Coll Abbottabad 2015;27:287-91.

8. Ghalambor N, Matta JM, Bernstein L. Heterotopic ossification following operative treatment of acetabular fracture. An analysis of risk factors. Clin Orthop Relat Res 1994;305:96-105. [CrossRef]

9. Matta JM. Fractures of the acetabulum: accuracy of reduction and clinical results in patients managed operatively within three weeks after the injury. J Bone Joint Surg Am 1996;78:1632-45. [CrossRef]

10. Johnson EE, Matta JM, Mast JW, Letournel E. Delayed reconstruction of acetabular fractures 21-120 days following injury. Clin Orthop Relat Res 1994;305:20-30. [CrossRef]

11. Nixon JR. Late open reduction of traumatic dislocation of the hip. Report of three cases. J Bone Joint Surg Br 1976;58:41-3. [CrossRef]

12. Rowe CR, Lowell JD. Prognosis of fractures of the acetabulum. JBJS 1961;43:30-59. [CrossRef]

13. Kını H. Asetabulum Kırıkları. TOTBID Derg 2002;1:45-59.

14. Letournel E. The treatment of acetabular fractures through the ilioinguinal approach. Clin Orthop Relat Res 1993;292:62-76. [CrossRef]

15. Matta JM, Anderson LM, Epstein HC, Hendricks P. Fractures of the acetabulum. A retrospective analysis. Clin Orthop Relat Res 1986;205:230-40. [CrossRef]

16. Rickman M, Varghese VD. Contemporary acetabular fracture surgery: treading water or swimming upstream?. Bone Joint J 2017;99-B:112531. [CrossRef]

17. McDowell S, Mullis B, Knight BS, Dahners LE. Modified Ollier transtrochanteric approach for the treatment of acetabular fractures. Orthopedics 2012;35:e132-6. [CrossRef]

18. Matta JM, Merritt PO. Displaced acetabular fractures. Clin Orthop Relat Res 1988;230:83-97. [CrossRef]

19. Routt ML Jr, Swiontkowski MF. Operative treatment of complex acetabular fractures. Combined anterior and posterior exposures during the same procedure. J Bone Joint Surg Am 1990;72:897-904. [CrossRef]

20. Matta JM, Letournel E, Browner BD. Surgical management of acetabular fractures. Instr Course Lect 1986;35:382-97.

21. Suzuki T, Smith WR, Hak DJ, Stahel PF, Baron AJ, Gillani SA, et al. Combined injuries of the pelvis and acetabulum: nature of a devastating dyad. J Orthop Trauma 2010;24:303-8. [CrossRef]

22. Johnson EE, Kay RM, Dorey FJ. Heterotopic ossification prophylaxis following operative treatment of acetabular fracture. Clin Orthop Relat Res 1994;305:88-95. [CrossRef]

23. Bosse MJ, Poka A, Reinert CM, Ellwanger F, Slawson R, McDevitt ER. Heterotopic ossification as a complication of acetabular fracture. Prophylaxis with low-dose irradiation. J Bone Joint Surg Am 1988;70:1231-7.

24. Letournel E. Acetabulum fractures: classification and management. Clin Orthop Relat Res 1980;151:81-106, [CrossRef]

25. Letournel E. Diagnosis and treatment of nonunions and malunions of acetabular fractures. Orthopedic Clin North America 1990;21:769-88.

26. Tipton WW, D'Ambrosia RD, Ryle GP. Non-operative management of central fracture-dislocations of the hip. J Bone Joint Surg Am 1975;57:888-93. [CrossRef]

27. Tile M. Fractures of the acetabulum. Rockwood and Green's fractures in adults. 3rd ed. Philadelphia: Lipincott-Raven; 1991. p. 1442-79.

28. Shon HC, Choi S, Yang JY. Three-dimensional printing-assisted surgical technique with limited operative exposure for both-column acetabular fractures. Ulus Travma Acil Cerrahi Derg 2018;24:369-75. [CrossRef] 


\section{ORİIINAL ÇALIŞMA - ÖZET}

\section{Cerrahi olarak tedavi edilen asetabulum kırıkları: Prognozu hangi parametreler etkiler?}

\section{Dr. Utku Bilekdemir, ${ }^{1}$ Dr. Osman Civan, ${ }^{2}$ Dr. Ali Cavit, ${ }^{3}$ Dr. Hakan Özdemir ${ }^{4}$}

${ }^{1}$ Silifke Devlet Hastanesi, Ortopedi ve Travmatoloji Kliniği, Mersin

EImalı Devlet Hastanesi, Ortopedi ve Travmatoloji Kliniği, Antalya

${ }^{3}$ Uludağ Üniversitesi Tıp Fakültesi, Ortopedi ve Travmatoloji Anabilim Dalı, Bursa

${ }^{4}$ Akdeniz Üniversitesi Tıp Fakültesi, Ortopedi ve Travmatoloji Anabilim Dalı, Antalya

AMAÇ: Çalışmada, cerrahi yöntemlerle tedavi edilen asetabulum kırıklarında uyguladığımız cerrahi yaklaşımları, oluşan komplikasyonları ve elde edilen klinik ve radyolojik sonuçları değerlendirerek prognoz üstünde etkin olan parametreleri saptamak amaçlandı.

GEREÇ VE YÖNTEM: Ocak 1994-Ocak 2014 tarihleri arasında deplase asetabulum kırığı tanısıyla cerrahi tedavi uygulanan I 44 olgudan, en az iki yıl süreyle klinik ve radyolojik takipleri yapılan (ortalama takip süresi 34 ay, dağılımı 2-8 yıl) ve yaş ortalaması 36.3 yıl (I 9-67 yıl) olan 75'i erkek, 28'i kadın toplam 103 hasta çalışmaya alındı.

BULGULAR: Hastaların klinik olarak \%64'ünde mükemmel ve iyi, \%36'sında orta ve kötü sonuç, radyolojik olarak ise \%57.3'ünde mükemmel ve iyi, \%42.7'sinde orta ve kötü sonuç elde edildi. Kırı̆̆ın kompleks olması (ki-kare $p=0.023$ ), travma ile operasyon arası sürenin artması ( $p=0.039$ ), cerrahi sürenin altı saatten uzun sürmesi (ki-kare $p<0.00$ I), eklem içi basamaklaşmanın 3 mm'den fazla olması (Fisher's $p=0.033$ ), mekanik blok oluşturan komplikasyonların gelişmesi (ki-kare $p<0.00$ I) klinik sonuçları kötüleştirmekteydi. Hastaların yaşının klinik sonuç üzerine anlamlı etkisi yoktu $(p=0.46 I)$.

TARTIŞMA: Cerrahi olarak tedavi edilen asetabulum kırıklarının prognozuna etki eden üç temel parametrenin; kırık tipi, cerrahi girişim süresi ve redüksiyon kalitesi olduğu, travma ile operasyon arasında geçen sürenin sonuçları dolaylı olarak etkilediği, avasküler nekroz, heterotropik ossifikasyon ve artirtin ise sadece uzun dönem sonuçları üzerinde olumsuz etkiler yarattı̆̆ı tespit edildi.

Anahtar sözcükler: Asetabulum; asetabulum kırıkları; asetabulum kırıkları cerrahi tedavisi; asetabulum kırıkları prognozu; kırıklar; pelvis kırıkları.

Ulus Travma Acil Cerrahi Derg 2020;26(2):265-273 doi: 10.14744/tjtes.2019.88472 